\title{
ОРГАНІЗАЦІЙНО-ТАКТИЧНІ ОСНОВИ ПРИЗНАЧЕННЯ ЕКСПЕРТИЗ ПІД ЧАС РОЗСЛІДУВАННЯ ЕКОНОМІЧНИХ ЗЛОЧИНІВ
}

Холостенко А. В., Мотрук В. А.

\begin{abstract}
У науковій cmammi розглянуто найбільш актуальні проблеми проведення та використання судових експертиз у кримінальному провадженні під час розслідування економічних злочинів. Висвітлені наукові, правові та організаційно-тактичні засади підготовки та призначення судових експертиз під час розслідування економічних злочинів, провадження експертного дослідження й використання результатів експертиз під час досудового розслідування. Досліджено особливості призначення експертиз під час розслідування економічних злочинів. Запропоновано способи розв'язання проблеми залучення фахівців окремих галузей знань до проведення судових експертиз, типових для злочинів чієї категорії. Розглядається ряд організаційних та процесуальних етапів порядку призначення експертиз під час розслідування економічних злочинів, який включає: визначення виду експертизи, яку необхідно призначити; перелік питань, які необхідно поставити перед експертом; перелік матеріалів, які необхідно надати експерту; вибір експерта або групи експертів при комісійній експертизі; винесення постанови про призначення експертизи; ознайомлення підозрюваного чи обвинуваченого з дорученням про проведення експертизи та роз'яснення йому прав; направлення документа про призначення експертизи та необхідні матеріали до експертної установи; вручення копії доручення експерту. Розглянуто процесуальний порядок судово-експертної діяльності та показано значення, яке відіграє висновок експерта в процесі доказування економічних злочинів.
\end{abstract}

Досліджено особливості призначення окремих видів судових експертиз, зокрема, судово-економічних (планово-економічної, фінансово-економічної), судово-бухгалтерських (експертиза бухгалтерських операцій на підприємствах, організаціях), судово-товарознавчої, судово-технологічної, криміналістичних (почеркознавчої, техніко-криміналістичної експертизи документів). Визначено, що за потреби дослідження питань з інших галузей знань, зумовленої певною слідчою ситуацією, слідчий може призначити й інші судові експертизи.

Ключові слова: судова експертиза, висновок експерта, експерт, призначення експертиз, завдання експертизи, досудове розслідування, економічні злочини.
Holostenko A. V., Motruk V. A. Organizational and tactical basis of appointment of examinations in the investigation of economic crimes

The scientific article considers the most pressing problems of conducting and using forensic examinations in criminal proceedings in the investigation of economic crimes. The scientific, legal and organizational-tactical principles of preparation and appointment of forensic examinations in the investigation of economic crimes, conducting expert research and using the results of examinations during the pre-trial investigation are covered. The peculiarities of the appointment of examinations in the investigation of economic crimes have been studied. Ways to solve the problem of involving specialists in certain fields of knowledge in conducting forensic examinations, typical for crimes of this category, are proposed. A number of organizational and procedural stages of the procedure for appointing examinations in the investigation of economic crimes are considered, which includes determining which examination should be appointed; what questions should be asked to the expert; what materials need to be provided; selection of an expert or group of experts during the commission examination; making a decision on the appointment of examination; acquainting the suspect or accused with the order to conduct an examination and explain his rights; sending a document on the appointment of the examination and the necessary materials to the expert institution; handing over a copy of the expert's decision. The procedural order of forensic activity is considered and the significance of the expert's opinion in the process of proving economic crimes is shown. The peculiarities of the appointment of certain types of forensic examinations, in particular, forensic economic (planning and economic, financial and economic), forensic accounting (examination of accounting transactions at enterprises, organizations); forensic commodity; forensic technology; forensic (handwriting, technical and forensic examination of documents). It is determined that if the needs of research in other areas of knowledge, due to a certain investigative situation, the investigator may appoint other forensic examinations.

Key words: forensic examination, expert opinion, expert, appointment of examinations, tasks of examination, pre-trial investigation, economic crimes.

( Холостенко А. В., Мотрук В. А., 2020 
Постановка проблеми та її актуальність. Процес доказування $\epsilon$ важливим етапом під час розслідування кримінальних проваджень економічного спрямування. Він поділяється на збирання, оцінку та закріплення доказів, їх фактичне використання з метою встановлення винних осіб та їх притягнення до відповідальності. Під час розслідування економічних злочинів актуальним залишається призначення експертизи з метою отримання обґрунтованого опису досліджених питань, які виникають у процесі проведення досудового розслідування. Особливу увагу під час проведення досудового розслідування у кримінальному провадженні займають питання, який різновид експертизи необхідно призначити, які питання поставити експерту, які матеріали надати тощо. Уповноважена службова особа, яка ініціює проведення експертизи, має знайти відповіді на ці питання та залучити експерта (експертів). Найчастіше під час розслідування економічних правопорушень виникає потреба у призначенні судових експертиз та експертних досліджень у галузі бухгалтерського, податкового, фінансового обліку; фінансів та кредиту; банківської справи; фінансово-господарської діяльності підприємств, установ та організацій тощо. Саме отримання кваліфікованого висновку може відіграти вирішальну роль під час розкриття та розслідування економічних кримінальних правопорушень.

Аналіз останніх досліджень і публікацій. Основою даної статті стали праці таких науковців, як В.П. Бахін, В.В. Бірюков, Р.С. Бєлкін, Т.В. Варфаломеєва, В.І. Галаган, І.В. Гора, А.В. Іщенко, Н.І. Клименко, В.В. Лисенко, В.Г. Лукашевич, Є.Д. Лук'янчиков, М.В. Салтевський, В.Т. Маляренко, М.М. Михеєнко, В.С. Кузьмічов, Л.Д. Удалова, І.Л. Петрухін, В.М. Тертишник, О.Р. Ратінов, В.Ю. Шепітько, а також інших науковців, які зробили вагомий внесок у дослідження проблематики призначення судових експертиз у кримінальному провадженні під час розслідування економічних правопорушень (злочинів).

Мета статті полягає у дослідженні організаційно-тактичних основ призначення різних видів експертиз під час розслідування економічних кримінальних правопорушень; визначенні різновиду необхідної експертизи, порядку призначення експертизи та залучення відповідних осіб (експертів), які володіють спеціальними знаннями в галузі.

Виклад основного матеріалу. Відповідно до положень ст. 101 Кримінально-процесуального кодексу висновок експерта - це докладний опис проведення експертом досліджень та зроблені за їх результатами висновки, обґрунтовані відпо- віді на запитання, поставлені особою, яка залучила експерта, або слідчим суддею чи судом, що доручив проведення експертизи. Відповідно до положень ст. 242 КПК експерт залучається у разі наявності підстав для проведення експертизи за дорученням сторони кримінального провадження.

Порядок призначення експертиз під час розслідування економічних злочинів включає ряд організаційних та процесуальних етапів, до яких потрібно віднести таке: визначення виду експертизи, яку необхідно призначити; перелік питань, які необхідно поставити перед експертом; перелік матеріалів, які необхідно надати експерту; вибір експерта або групи експертів при комісійній експертизі; винесення постанови про призначення експертизи; ознайомлення підозрюваного чи обвинуваченого з дорученням про проведення експертизи та роз'яснення йому прав; направлення документа про призначення експертизи та необхідні матеріали до експертної установи; вручення копії доручення експерту.

Під час розслідування економічних злочинів переважно досліджують фінансово-господарські документи, з'ясовують питання виробничого характеру. Зокрема, призначають i проводять такі види судових експертиз: судово-економічні (планово-економічну, фінансово-економічну), судово-бухгалтерські (експертизи бухгалтерських операцій на підприємствах, організаціях); судово-товарознавчу; судово-технологічну; криміналістичні (наприклад, почеркознавчу, техніко-криміналістичну експертизу документів, трасологічну); інженерно-технічні; судово-агропромислові. За потреби дослідження питань з інших галузей знань слідчий може призначити й інші судові експертизи.

Призначення криміналістичної експертизи документів. При вчиненні економічних злочинів переважно використовуються підроблені документи, у зв'язку з чим призначаються почеркознавча і техніко-криміналістична (технічна) експертизи документів [1, с. 274]. Особливості призначення технічної експертизи документів (вона поділяється на експертизу реквізитів документів і експертизу матеріалів документів) зумовлені наступними факторами: по-перше, широке використання в підприємницькій діяльності документів, виготовлених за допомогою комп'ютерної і копіювально-розмножувальної техніки; по-друге, використання кліше печаток і штампів, виготовлених за технологією зарубіжних фірм. Під час підготовки і призначення технічної експертизи документів, виготовлених на друкувальних пристроях (принтерах) персональних комп'ютерів 
(ПК), копіювально-розмножувальних апаратах, треба виходити з наступних положень.

1. При складанні документів на ПК в друкуванні знаків «беруть участь» і залишають сліди друку вальний картридж принтера (матричний, цівковий, лазерний) i програмне забезпечення (шрифти), закладене в ПК і принтер. Крім того, на документі залишаються сліди від принтера. Це зумовлює необхідність призначення зазвичай комплексної експертизи. Для їі проведення залучаються експерт-криміналіст 3 технічного дослідження документів і експерт з комп'ютерної техніки і програмного забезпечення. Останній досліджує програмне забезпечення ПК і принтера, яке зберігається на магнітних носіях, і відтворює відповідні шрифти за допомогою принтера як зразків для криміналістичного дослідження.

2. Під час виготовлення копії документу копіювально-розмножувальні апарати новітніх моделей за допомогою цифрових інтерфейсів здатні не тільки копіювати, але і сканувати зображення та друкувати ïx як лазерні принтери. Відмінність копій, одержаних з одного оригіналу на апаратах різних фірм і моделей, виявляється в кольоровій гаммі, відтінках, чіткості, яскравості, наявності чи відсутності растра і кодових позначень. Ці ознаки у сукупності характеризують групу моделей чи певну модель копіювального апарата, що дає змогу вирішувати діагностичні і класифікаційні завдання.

3. Сучасний рівень криміналістичних досліджень названих документів дозволяє: а) встановити факт виготовлення документу з використанням комп'ютерної техніки чи одержання копії за допомогою копіювально-розмножувальної техніки; б) вирішувати діагностичні, а в окремих випадках і ідентифікаційні завдання за документами, виготовленими за допомогою цівкових, лазерних принтерів та копіювально-розмножувальної техніки; в) ідентифікувати матричні принтери за виготовленими з їх допомогою документами [2, с. 96].

У разі призначення технічної експертизи документа, виготовленого з використанням комп'ютерної чи копіювально-розмножувальної техніки, треба мати на увазі, що при наданні експертові тільки документів, можуть бути вирішені наступні проблеми: 1) спосіб виготовлення документа (діагностичне завдання); 2) вид та модель технічного засобу, за допомогою якого було виготовлено документ (діагностичне завдання); 3) факт виготовлення кількох документів за допомогою одного і того ж конкретного технічного засобу (ідентифікаційне завдання). При наданні експертові документів і технічного обладнання, що перевіряється, вирішується проблема з ідентифікації цього обладнання.
Під час підготовки і призначення технічної експертизи документів, де об'єктом дослідження $\epsilon$ відбитки кліше печаток і штампів, виготовлених за технологією зарубіжних фірм, треба виходити з наступних положень.

1. Нормативними актами, які регулюють порядок замовлення і виготовлення печаток і штампів, встановлюється тільки розмір їх рамок, але не регламентується конфігурація шрифту і його розміри, які добираються довільно або з урахуванням вимог замовника.

2. У відбитках кліше печаток і штампів, виготовлених фотополімерним способом, ідентифікаційні ознаки (загальні і окремі) $€$ нестійкими і залежать від різноманітних умов: сили натискання, температури, структури і якості паперу. Це суттєво ускладнює вирішення питання про нанесення відбитка на документі конкретною печаткою, штампом (ідентифікацію кліше).

3. У разі призначення експертизи для вирішення ідентифікаційних завдань в розпорядження експерта треба надавати велику кількість порівняльного матеріалу (експериментальних і вільних зразків за різні періоди), а також кліше печатки чи штампу, що перевіряється [3, с. 103].

Призначення комп'ютерно-технічної експертизи. Експертизи комп'ютерної техніки в залежності від завдань, що вирішуються, поділяються на два різновиди: 1) технічну експертизу комп'ютерів, їх вузлів та пристроїв (встановлення призначення і характеристик комп'ютерної техніки, їі технічного стану; можливостей використання для досягнення певною мети тощо); 2) експертизу даних та програмного забезпечення (виявлення інформації, що міститься на комп'ютерних носіях, та визначення їі цільового призначення; відновлення «зітертої» інформації; розшифровка закодованих файлів; встановлення характеру змін, внесених в програми, і т. ін.) [4, с. 73].

Експертом може бути вирішений наступний орієнтовний перелік питань: 1) які технічні несправності має даний комп'ютер або його окремі блоки та пристрої і як ці несправності впливають на роботу комп'ютера? 2) чи міститься на даному носії якась інформація, і якщо так, то яке їі цільове призначення? 3) чи є на носії інформація, що була знищена, і чи можна їі відновити? 4) чи можливе вирішення певного завдання за допомогою даного програмного продукту? 5) чи відповідає стиль програмування досліджуваного програмного продукту стилю програмування певної особи? 6) яка вартість програмного забезпечення (на час його придбання, вилучення, проведення експертизи)? 7) яка вартість окремих модулів, що входять до складу програмного продукту? та ін. 
Під час підготовки і призначення комп'ютерно-технічної експертизи треба виходити з наступних положень.

1. Для дослідження інформації, що міститься на комп'ютерних носіях, експертові необхідно надавати сам комп'ютерний носій, а також комп'ютерний комплекс, до складу якого входить досліджуваний носій.

2. Для встановлення відповідності програмних продуктів певним параметрам, а також вартості програмного продукту експертові надається носій з копією досліджуваного програмного продукту і еталонна (дистрибутивна) копія програмного продукту.

3. Для дослідження технічного стану і визначення вартості комп'ютерної техніки експертові надається сама комп'ютерна техніка, а також технічна документація до неї.

4. Для встановлення авторства досліджуваного програмного продукту експертові надаються самі програми у вигляді вихідних текстів, бібліотечних та виконуваних модулів, а також програми (вихідні тексти, бібліотечні та виконувані модулі), що створені особою, щодо якої перевіряється версія: чи вона $є$ автором досліджуваного продукту.

Призначення судово-бухгалтерської експертизи. Розслідування економічних злочинів неможливе без аналізу фінансово-господарчої діяльності конкретної підприємницької структури, а іноді кількох підприємств і комерційних банків. Судово-бухгалтерську експертизу призначають у разі, якщо виникли сумніви щодо повноти, об'єктивності, професійності проведеної ревізії та застосованих ревізорами методів, а також за необхідності перевірити правильність оформлення окремих фінансово-господарських операцій. Залежно від особливостей конкретної галузі діяльності можуть призначати судові експертизи бухгалтерських операцій і документації в різних галузях господарства. Призначенню судово-бухгалтерської експертизи передує робота, яка включає в себе ретельне вивчення матеріалів кримінального провадження, вилучення та вивчення додаткових документів, допити службових осіб щодо фінансово-господарських операцій та інші відповідні слідчі (розшукові) дії. Передчасне призначення експертизи тягне за собою запити експертами додаткових матеріалів для належного проведення дослідження, що значно подовжує строки їі проведення [5, с. 232].

Предметом судово-бухгалтерської експертизи $\epsilon$ дослідження бухгалтерських операцій з обліку товарно-матеріальних цінностей і грошових коштів, що знайшли відображення в документах бухгалтерського обліку, контролю та звітності. Головними завданнями бухгалтерської експертизи у кримінальних провадженнях щодо економічних злочинів $\epsilon$ встановлення: 1) правильності складання балансу підприємства; 2) правильності документального оформлення операцій щодо приймання, зберігання, реалізації товарно-матеріальних цінностей і руху грошових коштів; 3) відповідності відображення в бухгалтерському обліку фінансово-господарських операцій вимогам чинних нормативних актів з бухгалтерського обліку і звітності; 4) кола осіб, на яких покладено обов'язок забезпечити дотримання вимог нормативно-правових актів з бухгалтерського обліку і контролю; 5) правильності визначення оподаткованого прибутку (доходу) підприємств різних форм власності та нарахування розмірів податків; 6) недоліків в організації бухгалтерського обліку контролю, які сприяли або могли сприяти завданню матеріальної шкоди або перешкоджали їі своєчасному виявленню.

Під час підготовки і призначення судово-бухгалтерської експертизи треба виходити з наступних положень.

1. Разом з дорученням про призначення експертизи експертові слід надати документи бухгалтерського обліку, які містять вихідні дані для вирішення поставлених питань.

2. Документи, що надаються експертові, мають бути систематизованими (за епізодами діяння, періодами тощо), підшитими, прошнурованими та пронумерованими.

Призначення фінансово-економічної експертизи. Під час розслідування економічних злочинів в багатьох випадках виникає необхідність залучення не тільки бухгалтерських, але і спеціальних знань у галузі фінансів та кредитування. Вивчення матеріалів кримінальних проваджень вказаної категорії свідчить, що слідчі досить часто в дорученнях про призначення судово-бухгалтерських експертиз ставлять саме такі питання. В такому разі дослідженню підлягає саме фінансово-економічна сторона діяльності підприємства, яка має своє коло питань і відповідну методику дослідження. В криміналістиці і теорії судової експертизи ці дослідження одержали назву фінансово-економічної експертизи.

Головними завданнями фінансово-економічної експертизи є встановлення: 1) джерел формування фінансових ресурсів підприємства; 2) дотримання правил нарахування і строків внесення податків та інших обов'язкових платежів; 3) дотримання правил фінансування і кредитування, встановлених чинним законодавством (в тому числі валютного законодавства); 4) платоспроможності підприємства (спроможність виконувати зобов'язання перед постачальниками, кредиторами, державою, акціонерами і власними працівниками); 5) дотри- 
мання законодавства про зовнішньоекономічну діяльність; 6) призначення витрачання кредитних коштів; 7) призначення витрачання коштів, одержаних з бюджетного фінансування; 8) достатність підстав для перерахування коштів за межі України; 9) фактів повернення коштів або матеріальних цінностей на територію України.

Перед експертом можуть бути поставлені й інші завдання, виконання яких пов'язано з перевіркою джерел формування і використання фінансових ресурсів підприємства, його фінансовим становищем, платоспроможності, додержання відповідного законодавства.

Під час підготовки і призначення фінансово-економічної експертизи треба мати на увазі, що експерт проводить дослідження в межах поставленого завдання тільки на основі тих документів, які залучені до кримінального провадження i надані йому слідчим. Правила оформлення і надання документів $є$ загальними для судовобухгалтерської і фінансово-економічної експертиз. Передусім можливості фінансово-економічної експертизи залежать від того, наскільки в представлених матеріалах первинних перевірок i документах знаходять відбиття фінансова сторона діяльності підприємства, суми заподіяної шкоди, конкретні правопорушення посадових осіб, їх детальні пояснення, недоліки бухгалтерського обліку та їх вплив на фінансовий стан підприємства тощо [6,с.52]. Якщо слідчий зазнає труднощів у визначенні документів, які необхідні для надання експертного висновку, то йому необхідно звернутися за консультацією до спеціаліста.

Висновки. Підсумовуючі викладене відносно підготовки і призначення експертиз, треба зазначити, що збирання й оцінка доказів за кримінальними провадженнями про економічні злочини зумовлює потребу використання різноманітних спеціальних знань, а конкретний спосіб застосування таких знань та/або вибір певного виду судових експертних досліджень зумовлені як видом економічного злочину, так і способами його вчинення та наявними в розпорядженні органів досудового розслідування чи суду матеріалами. На цей час найбільшими можливостями розглянутих експертних досліджень володіють науково-дослідні інститути судових експертиз Міністерства юстиції України. Орієнтиром під час підготовки і призначення таких експертиз можуть бути «Науково-методичні рекомендації з питань підготовки та призначення судових експертиз», затверджені наказом Міністерства юстиції України №53/5 від 08.10.1998 р. [7].

\section{Література}

1. Щербаковський М.Г. Проведення та використання судових експертиз у кримінальному провадженні : монографія. Харків : В деле, 2015. 560 с.

2. Липовский В.В., Лутонина Г.Д., Мороз Т.И., Прохоров-Лукин Г.В., Юрченко О.Б. К вопросу о возможности идентификации матричных принтеров по изготовленным с их помощью документам. Актуальные вопросы судебной экспертизы и криминалистики на современном этапе судебно-правовой реформы (к 75-летию основания Харьк. НИИ судебных экспертиз им. засл. проф. Н.С.Бокариуса). Харьков: Право. 1998. С. 96-98.

3. Кривошеев В.И. Об исследовании оттисков печатей и штампов, нанесенных клише, изготовленными в Украине по технологии зарубежных фирм. Актуальные вопросы судебной экспертизы и криминалистики на современном этапе судебно-правовой реформы (к 75-летию основания Харьк. НИИ судебных экспертиз им. засл. проф. Н.С. Бокариуса). Харьков : Право. 1998. С. 103-106

4. Россинская Е.Р. Судебная экспертиза в уголовном, гражданском, арбитражном процессе. Москва : Право и закон, 1996. 224 с.

5. Фрідман І.Я., Рогоза В.М. Судово-економічні дослідження в розслідуванні та попередженні злочинів та інших правопорушень в умовах ринкових відносин. Актуальные вопросы судебной экспертизы и криминалистики на современном этапе судебно-правовой реформы (к 75-летию основания Харьк. НИИ судебных экспертиз им. засл. проф. Н.С. Бокариуса). Харьков : Право. 1998. С. 232-233.

6. Шляхов А., Ромашов А. Судебная планово-экономическая и финансово-бухгалтерская экспертизы. Соц. Законность. 1980. № 4. С. 51-53.

7. Науково-методичні рекомендації з питань підготовки та призначення судових експертиз: затверджені наказом Міністерства юстиції України № 53/5 від 08.10.1998 р. Офіційний вісник України. 1998. № 46 /Із змінами, внесеними наказом МЮ від 26.12.2012 № 1950/5, ст. 178-182.

Холостенко А. В., кандидат юридичних наук, доцент, професор кафедри кримінального процесу Одеського державного університету внутрішніх справ

Мотрук В. А., аспірант кафедри кримінального процесу Одеського державного університету внутрішніх справ 